\title{
The measure mix matters: multiple-component plant protection is indispensable for coping with the enormous genome plasticity and mutation rates in pathogenic microorganisms
}

\author{
Ely Oliveira Garcia ${ }^{1} \cdot$ Andreas von Tiedemann $^{2} \cdot$ Holger B. Deising ${ }^{3}$
}

Received: 7 October 2020 / Accepted: 6 November 2020 / Published online: 30 November 2020

(c) The Author(s) 2020, corrected publication 2020

\begin{abstract}
Efficient plant protection is of fundamental importance in order to warrant food security. Here, we present arguments that a coordinate approach in plant protection is urgently required, taking advantage of a broad mix of measures, including modern synthetic chemistries, capable of protecting plants from adverse organisms.
\end{abstract}

Keywords AVR-genes $\cdot$ Breaking of resistance genes $\cdot$ Fungicides $\cdot$ Fungicide resistance $\cdot$ Genome plasticity $\cdot$ Mutations . Pesticides $\cdot$ Plant protection $\cdot$ R-genes

Plant disease outbreaks have threatened food security since ancient times and impact global economy today. Effective plant protection is thus of fundamental importance to overcome the threats caused by plant pathogens.

In environmental terms, resistance breeding is the method of choice to control plant diseases, in the best-case scenario conferring effective protection without additional costs for pesticides or labor during the growing season. Durable resistance $(R$-) gene-mediated resistance, however, with the exception of $m l o$-based resistance to powdery mildews in

Holger B. Deising

holger.deising@landw.uni-halle.de

Ely Oliveira Garcia

eoliveiragarcia@agcenter.lsu.edu

Andreas von Tiedemann

atiedem@gwdg.de

1 Department of Plant Pathology and Crop Physiology, College of Agriculture, Louisiana State University Agricultural Center, 302 Life Sciences Building, Baton Rouge, LA 70803, USA

2 Chair for Plant Pathology and Crop Protection, Department of Crop Science, Faculty of Agricultural Sciences, Georg-August University Göttingen, Grisebachstr. 6, 37077 Göttingen, Germany

3 Chair for Phytopathology and Plant Protection, Institute for Agricultural and Nutritional Sciences, Faculty of Natural Sciences III, Martin-Luther-University Halle-Wittenberg, Betty-Heimann-Str. 3, 06120 Halle (Saale), Germany cereals, has not been observed, as classical $R$-genes are rapidly overcome. Indeed, considerable genome variability in pathogen populations may be caused by transposable elements, high mutation and recombination rates as well as by incorrect chromosome segregation during mitosis and meiosis, collectively resulting in rapidly evolving new virulence phenotypes infecting formerly resistant cultivars (Möller et al. 2017).

Today, molecular mechanisms employed by fungal and bacterial pathogens during plant attack are well understood. Plants exhibit immunity to most microorganisms, mediated by distinct layers of resistance. The first layer of the plant immune system is activated by plant pattern recognition receptors (PRRs) upon contact with pathogen-associated molecular patterns (PAMPs), which are essential for pathogens and therefore structurally invariable molecules such as chitin and branched $\beta$-glucan fungal cell wall fragments or bacterial flagellin. As a result of PAMP recognition, PAMPtriggered immunity (PTI) is established. Successful pathogens, however, have developed mechanisms to circumvent PAMP recognition, e.g., by modifying their cell surfaces and PAMP exposure, and/or by secreting effectors (OliveiraGarcia and Valent 2015).

A significant breakthrough in molecular understanding of resistance genetics was Harold H. Flor's X-ray mutagenesis experiment with heterokaryotic flax rust urediniospores (Flor 1958), eventually giving rise to the gene-forgene hypothesis. This hypothesis suggested that microbial avirulence $(A V R-)$ gene products are recognized by plant 
$R$-gene products, with recognition causing rapid activation of defense responses such as the hypersensitive response $(H R)$. Today, AVR gene products are known as effector proteins, and the rapid resistance established by recognition of effectors is called effector-triggered immunity (ETI). Today, Flor's gene-for-gene hypothesis (Flor 1971) has been fully confirmed on the molecular level (Dangl and Jones 2001) and paved the way for molecular cloning and employment of plant $R$-genes in molecular breeding.

In spite of significant contributions of classical breeding to plant health, and in spite of significant efforts to introduce novel $R$-genes into crops, classical breeding is by far not sufficient to compensate for the loss of $R$-genes efficiency by rapidly occurring novel virulent pathogen races. Among the best-studied examples of genetic variability is the differentiation of races of the rice blast fungus Magnaporthe oryzae. The genome of M. oryzae is remarkably rich in transposable elements, and many effector genes are localized at telomere regions, contributing to genetic instability of these genes. Effector genes may also be localized on dispensable minichromosomes not transferred to the progeny of the pathogen (Peng et al. 2019). Furthermore, mutations caused by UV irradiation may also result in alteration of the effector gene complexity in pathogens, failure of effector-recognition and of resistance responses to occur (Fig. 1).

Indeed, in the late 1980s, rice blast disease was widespread in Arkansas, causing severe yield losses. In 1990, the first blast-resistant rice cultivar harboring the $R$-gene $P i$-ta was released, and several rice cultivars carrying this gene have subsequently been developed to control the disease. However, due to the enormous variability of the effector gene AVR-Pital in natural populations of $M$. oryzae, $P i$ $t a$ was broken and spread of the novel races IB-17, IB-49 and IC-17 caused new rice blast outbreaks between 2012 and 2015 (Peng et al. 2019). Similar scenarios have been reported for the powdery mildew fungus Blumeria graminis f. sp. hordei, which was able to overcome several $R$-genes, including Mla12, Mla7, Mla9, Mla13 and Mlk1 within two to four years after their release in commercial barley cultivars in the 1970s to 1990s. In this fungus, breaking of $R$-genes by effector gene mutations is not surprising, given that up to $10^{13}$ spores can daily be released per ha of an infected field, and given mutation frequencies in the range of $1 \times 10^{-6}$ to $1 \times 10^{-5}$ (Deising et al. 2002). More recent examples of virulence shifts are the occurrence of the wheat stem rust race UG99 and the outbreak of stripe rust in North Africa and Europe due to introduction of novel races from central Asia (Ali et al. 2017; Salcedo et al. 2017). These examples indicate that virulence evolution and overcoming a broad range of so far efficient $R$-genes is a persisting threat to crop production. Thus, the enormous genome plasticity of pathogens, the acreage at which cultivars with given $R$-genes are grown, and particularly the volume of inoculum allowed
Avr recognition (resistance)
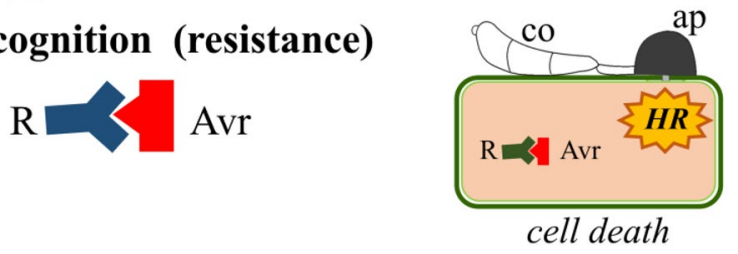

no recognition (susceptibility)
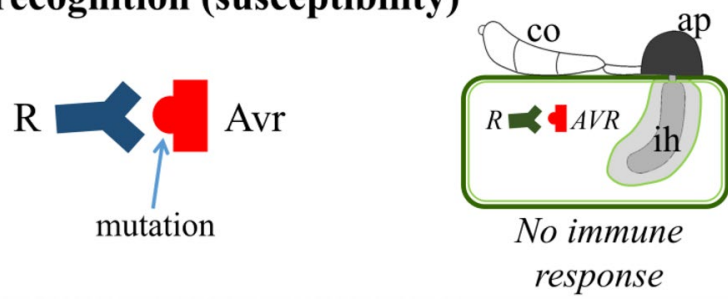

Fig. $1 A V R$ - and $R$-gene product interactions determine resistance or susceptibility. Recognition of fungal Avr protein (syn. effector protein) by cytoplasmic NBS-LRR resistance protein of the plant results in rapid defense responses, e.g., the hypersensitive response $(H R)$. Mutations in an effector gene may lead to failure in effector protein recognition, compromised defense responses and the establishment of disease. $a p$ appressorium, $A v r$ avirulence (syn. effector) protein, co conidium, $H R$ hypersensitive response, $R$ resistance protein $=\mathrm{Avr}$ receptor, $i h$ infection hypha.

to form by insufficient disease control measures can be regarded as the prime determinants of the limited durability of single $R$-genes.

The lesson learned from fast breaking of newly introduced $R$-genes by effector gene mutations is that support of $R$-genes by additional disease control measures is indispensable. Accelerated introduction of novel $R$-genes and efficient pyramidizing of these, supported by modern CrispR/ Cas-like genome editing technologies (Chen et al. 2019) would enormously reduce the time required for generating novel disease-resistant cultivars, strengthen plant health and likely reduce contaminations of harvest products with microbial toxins. However, ignoring scientific arguments, public and political reservations caused banning of these environment-friendly technologies.

As classical resistance breeding is not sufficient to protect crops, the demand for other methods warranting plant health and increasing yield is growing stronger. Among the available alternatives, QTL-based quantitative resistance may offer some reduction in disease symptom severity, but QTLs alone will only mitigate disease development and are hardly able to safeguard the sustainability of food and fodder production. Furthermore, biological control strategies, although publicly appreciated and politically supported, are today not sufficiently effective to control above-ground diseases and will-if ever-only cover small niches in disease control. As previously discussed, antagonistic microorganisms 
Table 1 Number of plantpathogen/pest interactions and herbicides with less than three chemistries with distinct targets in Germany

\begin{tabular}{llllllll}
\hline & 1973 & 1983 & 1993 & 2003 & 2008 & 2013 & 2018 \\
\hline Agronomy & & & & & & & \\
Fungicides & 21 & 55 & 65 & 104 & 115 & 110 & 199 \\
Herbicides & 54 & 162 & 243 & 376 & 490 & 535 & 545 \\
Insecticides & 35 & 51 & 75 & 82 & 95 & 146 & 195 \\
Vegetable production & & & & & & \\
Fungicides & 27 & 58 & 82 & 293 & 357 & 472 & 590 \\
Herbicides & 28 & 64 & 116 & 369 & 402 & 402 & 413 \\
Insecticides & 76 & 115 & 199 & 284 & 408 & 476 & 591 \\
Fruit production & & & & & & & \\
Fungicides & 17 & 34 & 44 & 68 & 80 & 111 & 141 \\
Herbicides & 16 & 29 & 36 & 50 & 80 & 90 & 97 \\
Insecticides & 40 & 84 & 87 & 123 & 131 & 114 & 150 \\
Total* & 510 & 1.024 & 1.307 & 2.194 & 2.657 & 2.993 & $3.539 * *$ \\
\hline
\end{tabular}

*Related to all applications and cultures, including forestry, ornamental plants, greenland and stored product protection

** Corresponds to $63.5 \%$ of all interactions between crops and adverse organisms $(=5.577)$

After Jeske (2019) employed in biological disease control may even result in increased microbial secondary metabolite synthesis in plant pathogen(s) and/or biological control agent(s), giving rise to biological chemistries of unpredictable toxicity and risks for consumers (Deising et al. 2017).

The above obstacles raise the question, which effective plant protection measures can be used. Today, farmers using synthetic chemistries to control diseases and pests are facing societal objection, and consumers are concerned because of the putatively toxicological profiles and persistence of pesticides. It should be emphasized here that pesticides, together with breeding of resistant cultivars of crops, have warranted increasing yield and yield stability over decades, and in contrast to the toxicity of the first generation of these compounds, the vast majority of currently registered plant protection chemistries is safe for consumers and environment. The irrationality in pesticide risk perception is obvious: Copper-based multi-target fungicides, which exhibit high acute toxicity (oral $\mathrm{LD}_{50}$ values in rats is $\sim 300 \mathrm{mg}$ / $\mathrm{kg}$ ) and ecotoxicity profiles (Baldwin et al. 2003; Paoletti et al. 1998) and are persistent in soil, can even be used in biological farming. Synthetic chemistries such as the quinone-outside-inhibitor kresoxim-methyl and the multi-target dithiocarbamate fungicide mancozeb exhibit $\mathrm{LD}_{50}$ values corresponding to $\sim 5000 \mathrm{mg} / \mathrm{kg}$. For comparison, the neurotoxic pyrethroid insecticides Cypermethrin and Cyfluthrin have oral $\mathrm{LD}_{50}$ values in rats of $\sim 420$ and $\sim 350 \mathrm{mg} / \mathrm{kg}$, and the $\mathrm{LD}_{50}$ of the neonicotinoid Thiacloprid corresponds to $620 \mathrm{mg} / \mathrm{kg}$. The corresponding value for Nicotine is in the range of $50-60 \mathrm{mg} / \mathrm{kg}$, indicating that the toxicity of this compound exceeds that of neurotoxic insecticides. Clearly, plant protection chemistries, applied in accordance with legal guidelines, exhibit a negligible risk for farmers and consumers.

The acute risk is not to intoxicate consumers or the environment by applying synthetic pesticides. The risk is to lose entire pesticide classes, so that certain targets in pathogens cannot be addressed further. The fewer chemistries with distinct targets exist, the more frequently pesticides with the same mode of action are applied, resulting in effective development of resistance against these compounds in pests and pathogens. Therefore, it is generally accepted that a minimum of three actives with distinct targets is required to minimize the risk of development of pesticide resistance (Anonymous 2013; Jeske 2019). The concern to lose plant protection chemistries to the point that diseases, pests or weeds cannot be controlled is absolutely realistic: Jeske (2019) quantified the number of interactions between cultivated plants and adverse organisms and recorded the number of interactions for which less than three chemistries with distinct targets are available. In 1973, for only 510 out of 5.577 interactions less than three chemistries with distinct modes-of-action were available. Remarkably, in 2018, this value had increased to 3.539 , corresponding to $63.5 \%$ of all interactions (Tab. 1). Clearly, due to the enormous genome plasticity and mutation rates in pathogens, occurrence of strains resistant to the few remaining plant protection chemistries is hard to prevent. The dramatic scenario of loss of the complexity of plant protection chemistries (Table 1) and the absence of effective alternatives indeed bear the risk of failure of disease or pest control in the future.

Our prime concern should be that on a worldwide scale, approximately, 700 million people are undernourished at present, urgently requiring the development of modern plant 
disease control measures. In this context, banning pesticides and modern transgene technologies will not support food security. The key to effective plant protection lays in strict science-based and coordinate development and employment of all measures, including searching for novel chemistries, pyramiding of $R$-genes, adopting molecular plant breeding technologies and to carefully evaluate biological control agents before legislation (Deising et al. 2017). In addition, development of modern pesticide application strategies and sufficiently diverse cropping schemes may support successful plant protection. For example, cultivar-specific application of fungicides, depending on the performance of the $R$-genes, may lead to cross-protection of pesticides and $R$-genes and extend the lifetimes of both (Chen 2014). Given the enormous genome plasticity and mutation rates in pathogenic microorganisms, there is no alternative to coordinately employing multiple components in plant protection.

Funding Open Access funding enabled and organized by Projekt DEAL. We also acknowledge support of the Louisiana State University Agricultural Center.

Open Access This article is licensed under a Creative Commons Attribution 4.0 International License, which permits use, sharing, adaptation, distribution and reproduction in any medium or format, as long as you give appropriate credit to the original author(s) and the source, provide a link to the Creative Commons licence, and indicate if changes were made. The images or other third party material in this article are included in the article's Creative Commons licence, unless indicated otherwise in a credit line to the material. If material is not included in the article's Creative Commons licence and your intended use is not permitted by statutory regulation or exceeds the permitted use, you will need to obtain permission directly from the copyright holder. To view a copy of this licence, visit http://creativecommons.org/licenses/by/4.0/.

\section{References}

Ali S, Rodriguez-Algaba J, Thach T, Sørensen CK, Hansen JG, Lassen P, Nazari K, Hodson DP, Justesen AF, Hovmøller MS (2017) Yellow rust epidemics worldwide were caused by pathogen races from divergent genetic lineages. Front Plant Sci 8: article Nr. 1057
Anonymous (2013) Nationaler Aktionsplan zur nachhaltigen Anwendung von Pflanzenschutzmitteln. BMEL, Bonn

Baldwin DH, Sandahl JF, Labenia JS, Scholz NL (2003) Sublethal effects of copper on coho salmon: impacts on nonoverlapping receptor pathways in the peripheral olfactory nervous system. Environ Toxicol Chem 22:2266-2274

Chen XM (2014) Integration of cultivar resistance and fungicide application for control of wheat striperust. Can J Plant Pathol 36:311-326

Chen K, Wang Y, Zhang R, Zhang H, Gao C (2019) CRISPR/Cas genome editing and precision plant breeding in agriculture. Annu Rev Plant Biol 70:667-697

Dangl JL, Jones JDG (2001) Plant pathogens and integrated defence responses to infection. Nature 411:826-833

Deising HB, Reimann S, Peil A, Weber WE (2002) Disease management of rusts and powdery mildews. In: Kempken F (ed) The Mycota XI. Application in agriculture. Springer, Berlin, pp 243-269

Deising HB, Gase I, Kubo Y (2017) The unpredictable risk imposed by microbial secondary metabolites: how safe is biological control of plant diseases? J Plant Dis Prot 124:413-419

Flor HH (1958) Mutation to wider virulence in Melampsora lini. Phytopathology 48:297-301

Flor HH (1971) Current status of the gene for gene-concept. Annu Rev Phytoparthol 9:275-296

Jeske F (2019) Auswertung der Anzahl Resistenzklassen von Wirkstoffen für Pflanzenschutzmittelanwendungen. Saphir Verlag, Ribbesbüttel

Möller M, Eva H, Stukenbrock EH (2017) Evolution and genome architecture in fungal plant pathogens. Nat Rev Microbiol 15:756-771

Oliveira-Garcia E, Valent B (2015) How eukaryotic filamentous pathogens evade plant recognition. Curr Opin Microbiol 26:92-101

Paoletti MG, Sommaggio D, Favretto MR, Petruzelli G, Pezzarossa B, Barbafieri M (1998) Earthworms as useful bioindicators of agroecosystem sustainability in orchards and vineyards with different inputs. Appl Soil Ecol 10:137-150

Peng Z, Oliveira-Garcia E, Lin G, Hu Y, Dalby M, Migeon P, Tang H, Farman M, Cook D, White FF, Valent B, Liu S (2019) Effector gene reshuffling involves dispensable mini-chromosomes in the wheat blast fungus. PLoS Genet 15:e1008272

Salcedo A, Rutter W, Wang S, Akhunova A, Bolus S, Chao S, Anderson N, Fernandez De Soto M, Rouse M, Szabo L, Bowden RL, Dubcovsky J, Eduard Akhunov E (2017) Variation in the AvrSr35 gene determines $\mathrm{Sr} 35$ resistance against wheat stem rust race Ug99. Science 358:1604-1606

Publisher's Note Springer Nature remains neutral with regard to jurisdictional claims in published maps and institutional affiliations. 